\title{
Study on isolation, molecular detection of virulence gene and antibiotic sensitivity pattern of Escherichia coli isolated from milk and milk products
}

\author{
P. K. Virpari, J. B. Nayak, M. N. Brahmbhatt and H. C. Thaker \\ Department of Veterinary Public Health, \\ Veterinary College, Anand Agricultural University, Anand - 388 001, India \\ Corresponding author: Paresh K. Virpari, email:p.virpari@gmail.com \\ Received: 10-04-2013, Revised: 24-04-2013, Accepted: 24-04-2013, Published online: 01/06/2013
}

How to cite this article: Virpari PK, Nayak JB, Brahmbhatt MN and Thaker HC (2013) Study on isolation, molecular detection of virulence gene and antibiotic sensitivity pattern of Escherichia coli isolated from milk and milk products, Vet World 6(8): 541-545, doi:10.5455/vetworld.2013.541-545

\begin{abstract}
Aim: The study was undertaken to isolate pathogenic E. coli from milk and various milk products, detection of virulence gene using Polymerase chain reaction (PCR) and investigate their antibiotic sensitivity pattern.

Materials and Methods: Altogether 250 milk and various milk products samples consisting of raw milk (50), cheese (50), ice-cream (50), mawa (50) and dahi (50) were collected from milk vendors, retail shops located in Anand city, under aseptic precautions. For the enrichment of the organism from the collected samples, MacConkey broth was used and inoculation was carried out on MacConkey agar and EMB agar. Later on, to confirm the isolates, various biochemical tests such as IMViC test, Urease test were performed. Evaluation of antibiotic sensitivity pattern of E. coli was assessed by disk diffusion method. Finally the $E$. coli isolates were screened for the presence of virulence associated genes by PCR .

Results: The prevalence of $E$. coli was observed $32 \%$ in the samples comprising of milk (52.00\%), cheese (28.00\%), icecream $(20.00 \%)$, mawa $(44.00 \%)$, and dahi $(16.00 \%)$. Antibiotic sensitivity was recorded high for Co-trimoxazole (100\%) followed by Gentamicin (96.73\%), Trimithoprime (93.47\%) and Doxycycline hydochloride (92.39\%). Least sensitivity was recorded for Ampicillin (8.69\%). In this study, out of $80 \mathrm{E}$. coli isolates, 25 isolates $(31.25 \%)$ were positive for stx genes, of which $7(8.75 \%)$ isolates were positive for stx 1 gene only, while $12(15.00 \%)$ isolates were positive for stx 2 gene only and 5 $(6.25 \%)$ isolates were positive for both stx 1 and $s t x 2,7$ isolates (8.75\%) were positive for eaeA gene and all the isolate were negetive for $r f b \mathrm{O} 157$ gene.

Conclusions: Current study supports the finding that raw milk and various milk products can be regarded as critical source of pathogenic $E$. coli This explains the need of strict monitoring and surveillance for effective measures of hygiene and sanitary practice during production of milk and various milk products.
\end{abstract}

Keywords: antibiotic sensitivity test, enteropathogenic E. coli, milk, milk products, PCR

\section{Introduction}

Raw milk consumers have existed in various parts of the world. World milk production reached 724 million tons in 2010 as per Food and Agriculture Organization, resulting in trade and massive consumption of various milk products [1]. Raw milk is consumed directly by a large population in rural areas. Milk is an excellent medium for the growth of numerous microbes which produce consequential spoilage of the milk and various milk products or infections in consumers [2]. Because of the specific production, it is impossible to avoid contamination of milk with microorganisms therefore the microbial content of milk is a major feature in determining its quality [3]. The existence of food borne pathogens in raw milk may increases the threat of ingestion and transmission of food borne pathogens and ingestion of harmful toxins [4]. Huge numbers of microbes can get access to milk and various milk products including $E$. coli which is an indicator of fecal contamination, constituting a public health hazard.

This article is an open access article licensed under the terms of the Creative Commons Attribution License (http://creativecommons. org/licenses/by/2.0) which permits unrestricted use, distribution and reproduction in any medium, provided the work is properly cited.
The most important causes of food borne diseases are Shiga toxin-producing E. coli (STEC) among the other seropathotypes of E. coli [5]. STEC produce various complications including diarrhea, hemolytic uremic syndrome (HUS) and hemorrhagic colitis (HC) [6]. Report indicate that consumption of raw milk and various milk products related with occurrence of 1 to 5 per cent of food infections and among that 53 per cent of cases produced by enteropathogenic E. coli (EPEC) [7].

In view of the these particulars, the current study was undertaken to detect and characterize the E. coli from milk and various milk products, collected from the milk vendors, retail shops in and around Anand city, Gujarat.

\section{Materials and Methods}

Sample collection: Altogether 250 milk and various milk products samples consisting of raw milk (50), cheese (50), ice-cream (50), mawa (50) and dahi (50) were collected from milk vendors, retail shops located in Anand city, under aseptic precautions. The milk samples were collected in sterilized sample bottle and other milk products sample were collected in sterilized polyethylene bags in morning hours were transported to the P. G. research laboratory of the Veterinary Public 
Table-1. Details of primers used for PCR.

\begin{tabular}{|c|c|c|c|}
\hline Target Genes & Primer sequence $\left(5^{\prime} \rightarrow 3^{\prime}\right)$ & Product Size (bp) & References \\
\hline stx1 & $\begin{array}{l}\text { F:CAGTTAATGTGGTGGCGAAG } \\
\text { R:CTGCTAATAGTTCTGCGCATC }\end{array}$ & 894 & {$[11]$} \\
\hline stx2 & $\begin{array}{l}\text { F:CTTCGGTATCCTATTCCCGG } \\
\text { R:GGATGCATCTCTGGTCATTG }\end{array}$ & 478 & [11] \\
\hline eaeA & $\begin{array}{l}\text { F:GACCCGGCACAAGCATAAGC } \\
\text { R:CCACCTGCAGCAACAAGAGG }\end{array}$ & 384 & [12] \\
\hline rfbO157 & $\begin{array}{l}\text { F:AAGATTGCGCTGAAGCCTTTG } \\
\text { R:CATTGGCATCGTGTGGAC }\end{array}$ & 497 & [13] \\
\hline
\end{tabular}

Table-2. In vitro antimicrobial drug sensitivity of $E$. coli isolates from milk and milk products

\begin{tabular}{lllll}
\hline Sr. No. & Antimicrobial agents & Sensitive & Intermediate & Resistant \\
\hline 1 & Ampicillin & $7(8.75 \%)$ & $38(47.50 \%)$ & $35(43.75 \%)$ \\
2 & Kanamycin & $51(63.75 \%)$ & $20(25.00 \%)$ & $9(11.25 \%)$ \\
3 & Amikacin & $56(70.00 \%)$ & $12(15.00 \%)$ & $12(15.00 \%)$ \\
4 & Chloramphenicol & $64(80.00 \%)$ & $3(3.75 \%)$ & $13(16.25 \%)$ \\
5 & Oxytetracycline & $52(65.00 \%)$ & $8(10.00 \%)$ & $20(25.00 \%)$ \\
6 & Streptomycin & $35(43.75 \%)$ & $26(32.50 \%)$ & $19(23.75 \%)$ \\
7 & Gentamicin & $77(96.25 \%)$ & $3(3.75 \%)$ & $0(0.00 \%)$ \\
8 & Doxycycline hydrochloride & $73(91.25 \%)$ & $2(2.50 \%)$ & $5(6.25 \%)$ \\
9 & Ciprofloxacin & $63(78.75 \%)$ & $8(10.00 \%)$ & $9(11.25 \%)$ \\
10 & Trimithoprime & $74(92.50 \%)$ & $2(2.50 \%)$ & $4(5.00 \%)$ \\
11 & Levofloxacin & $68(85.00 \%)$ & $4(5.00 \%)$ & $8(10.00 \%)$ \\
12 & Cefotaxime & $70(87.50 \%)$ & $5(6.25 \%)$ & $5(6.25 \%)$ \\
13 & Nalidixic Acid & $60(75.00 \%)$ & $1(1.25 \%)$ & $19(23.75 \%)$ \\
14 & Co-trimoxazole & $0(0.00 \%)$ & $0(0.00 \%)$ \\
\hline
\end{tabular}

Health department in an ice box for further processing and microbiological analysis.

Isolation and identification: Samples were processed to isolate the E. coli as per the standard Bacteriological Analytical Manual (BAM), U.S. Food and Drug Administration (USFDA) method [8]. The samples were enrichmed in MacConkey broth, the loopful of culture inoculates MacConkey agar. Pink colour colonies obtain from MacConkey agar were taken and inoculate on Eosin methelene blue agar. Greenish metallic sheen colonies obtain on EMB agar were regard as an E. coli. Various biochemical tests such as catalase test, Indole production, Methyl red, Voges proskauer, Simon's citrate agar, Urease production, Nitrate reduction etc. were done for the confirmation of E. coli as proposed by Edward and Ewing [9].

Antibiotic sensitivity test: The antibiotic susceptibility tests were performed as per method described by Bauer et al. [10] to find out the antibiotic sensitivity of E. coli. In vitro antibiotic sensitivity test of the $E$. coli isolates was conducted by paper disc diffusion method using the discs supplied by HiMedia Laboratories Pvt. Ltd., Mumbai (India). Antibiotics used in this test viz. Kanamycin $(30 \mu \mathrm{g})$, Ampicillin $(10 \mu \mathrm{g})$, Streptomycin $(10 \mu \mathrm{g})$, Amikacin $(30 \mu \mathrm{g})$, Cefotaxime $(30 \mu \mathrm{g})$, Oxytetracycline $(30 \mu \mathrm{g})$, Trimithoprime $(5 \mu \mathrm{g})$, Doxycycline Hydochloride $(30 \mu \mathrm{g})$, Ciprofloxacin $(5 \mu \mathrm{g})$, Chloramphenicol $(30 \mu \mathrm{g})$, Nalidixic Acid $(30 \mu \mathrm{g})$, Gentamicin $(10 \mu \mathrm{g})$, Levofloxacin $5 \mu \mathrm{g})$ and Co-trimoxazole $(20 \mu \mathrm{g})$.

DNA isolation: The DNA of E. coli isolates was prepared by using boiling method. First $100 \mu \mathrm{l}$ of sterilized DNAse and RNAse free water was taken in micro centrifuge tube and approximately loopful of culture was added. Then denaturation was carried out at $95^{\circ} \mathrm{C}$ for $10 \mathrm{~min}$, centrifugation was done for the removal of cell debris and $3 \mu \mathrm{l}$ of the supernatant was used as a DNA template in PCR reaction mixture.

Polymerase chain reaction (PCR): All the E. coli isolates were first screened for the presence of virulence associated genes by using the PCR technique for the detection of different genes. The PCR was standardized for the detection stx 1, stx 2 , eaeA and $r f b$ O157 following the methodology as described by Paneto et al. [11] for detection of stx 1 \& stx 2 genes, ElJakee et al. [12] for detection of eaeA gene and Dhanashee and Mallaya [13] for detection of $r f b O 157$ with suitable modifications (Table-1). Standardization of PCR was done by using standard strain of $E$. coli O157:H7 and EPEC. The reactions were performed in the thermal cycler (Applied Biosystem, Sweden) with pre-heated lid (Lid temp. $105^{\circ} \mathrm{C}$ ). For the confirmation of targeted PCR amplification, consisting of $1 \mu 1$ of $6 \mathrm{X}$ gel loading buffer along with $5 \mu$ lof the PCR product, then electrophoresis was performed with use of DNA molecular weight marker (Gene Ruler, MBI Fermentas). Agarose gel (2\%) along with ethidium bromide (at the rate of $0.5 \mu \mathrm{g} / \mathrm{ml}$ ) was used. Electrophoresis was performed in $0.5 \mathrm{X}$ TBE buffer at $5 \mathrm{~V} / \mathrm{cm}$ for $60 \mathrm{~min}$. Visualization of amplified product was done under ultraviolet light and was documented by gel documentation system (SynGene, Gene Genius BioImaging System, UK).

\section{Results}

Prevalence of E. coli: The prevalence of E. coli was observed $32 \%$ cent in the samples comprising of milk $(52.00 \%)$, cheese $(28.00 \%)$, ice-cream $(20.00 \%)$, mawa (44.00\%), and dahi (16.00\%).

Prevalence of antibiotic sensitivity of $E$. coli: In present investigation among $80 \mathrm{E}$. coli isolates from milk and various milk products the highest sensitivity was 
Table-3. PCR amplification of virulence genes

\begin{tabular}{|c|c|c|c|c|c|c|}
\hline \multirow[t]{2}{*}{ Sr. No. } & \multirow[t]{2}{*}{ Virulence Genes } & \multicolumn{4}{|c|}{ E. coli isolates positive from } & \multirow[b]{2}{*}{ Dahi } \\
\hline & & Milk & Cheese & Ice cream & Mawa & \\
\hline 1 & stx1 & $2(8.00 \%)$ & $4(16.00 \%)$ & $3(12.00 \%)$ & $2(8.00 \%)$ & $1(4.00 \%)$ \\
\hline 2 & stx2 & $4(16.00 \%)$ & $5(20.00 \%)$ & $4(16.00 \%)$ & $5(20.00 \%)$ & $0(0.00 \%)$ \\
\hline 3 & eaeA & $1(4.00 \%)$ & $2(8.00 \%)$ & $2(8.00 \%)$ & $1(4.00 \%)$ & $1(4.00 \%)$ \\
\hline 4 & rfbO157 & $0(0.00 \%)$ & $0(0.00 \%)$ & $0(0.00 \%)$ & $0(0.00 \%)$ & $0(0.00 \%)$ \\
\hline
\end{tabular}

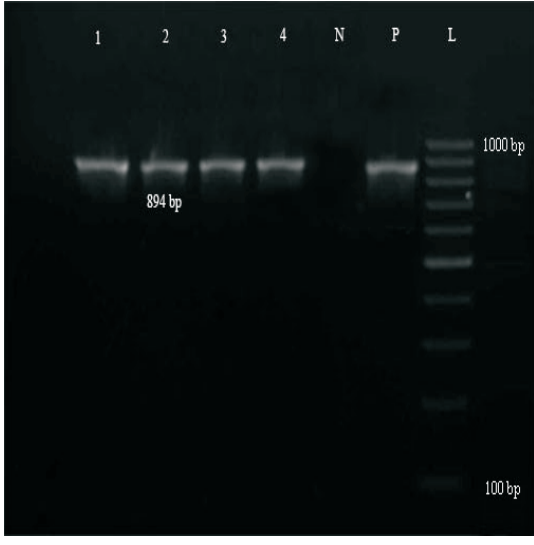

Figure-1. Agarose gel showing PCR amplification of $E$. coli stx 1 gene product (894 bp) P: Positive control, N: Negative control, L: DNA Ladder, Lane 1 to 4: Positive samples

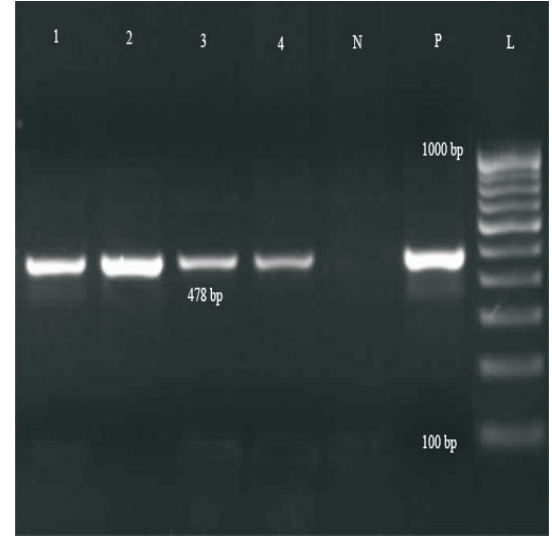

Figure-2. Agarose gel showing PCR amplification of $E$. coli stx 2 gene product (478 bp) P: Positive control, N: Negative control, L: DNA Ladder, Lane 1 to 4 : Positive samples

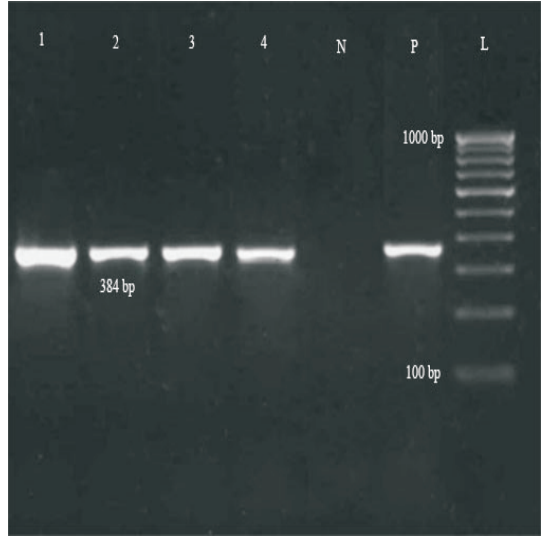

Figure-3. Agarose gel showing PCR amplification of $E$. coli eaeA gene product (384 bp) P: Positive control, $\mathrm{N}$ : Negative control, L: DNA Ladder, Lane 1 to 4: Positive samples recorded for Co-trimoxazole $(100 \%)$ and least for Ampicillin (8.75\%) (Table-2).

The highest resistance was observed against the Ampicillin (43.75\%) and least resistance was observed against Doxycycline Hydochloride (6.25\%), Cefotaxime $(6.25 \%)$, Trimithoprime $(5.00 \%)$ and no resistance was observed against Gentamicin, Cotrimoxazole (Table-2).

Detection of virulence genes: In this study, out of $80 \mathrm{E}$. coli isolates, 25 isolates $(31.25 \%)$ were positive for $s t x$ genes, of which $7(8.75 \%)$ isolates were positive for stx 1 gene only, while $12(15.00 \%)$ isolates were positive for stx 2 gene only and $5(6.25 \%)$ isolates were positive for both $s t x 1$ and stx2. $12(15.00 \%)$ isolates carried stx 1 genes and $18(22.50 \%)$ isolates had $s t x 2$ gene. In this study, 25 isolates from raw milk and various milk products found STEC (Table-3).

\section{Discussion}

Prevalence of $E$. coli: In present study prevalence of $E$. coli in milk is 52 per cent, almost similar result was found $(57 \%)$ by Soomro et al. [14]. However, lower prevalence of $E$. coli than present study was reported 26.43 per cent by Bandyopadhyay et al. [15], 30.28 per cent by Farzan et al. [16], 31.6 per cent by Nanu et al. [17] and 33.96 per cent by Mohd et al. [18]. Prevalence of $E$. coli reported 28 per cent in cheese, the similar result 29.2 per cent in Ras cheese was recorded by Fadel et al. [19]. Higher prevalence 96 per cent in cheese was reported by Paneto et al. (2007). However, lower prevalence of $E$. coli $(12.9 \%)$ in cottage cheese was reported by Singh and Prakash [20] and 16.6 per cent in cheese was reported by Farzan et al. [16]. Prevalence of ice-cream was found 20 per cent in present study; similar result of prevalence of $E$. coli in ice-cream was reported 16.6 per cent by Farzan et al. [16]. Fadel et al. [19] found that 31.8 per cent of icecream samples were positive for $E$. coli. In contrast with this study, high prevalence of $E$. coli $(58 \%)$ was recorded by Amany et al. [21].

Prevalence of antibiotic sensitivity of $\boldsymbol{E}$. coli: In present investigation among $80 \mathrm{E}$. coli isolates from milk and various milk products the highest sensitivity was recorded for Co-trimoxazole $(100 \%)$ and least sensitivity was recorded for Ampicillin (8.75\%).

The highest resistance was observed against the Ampicillin (43.75\%) and least resistance was observed against Doxycycline hydochloride (6.25\%), Cefotaxime $(6.25 \%)$, Trimithoprime $(5.00 \%)$ and no resistance was observed against Gentamicin, Co-trimoxazole.

Gentamicin, Kanamycin, Streptomycin and Amikacin are commonly used aminoglycosides in the treatment of various microbial infection. In the present study, 23.91 per cent of isolates were reported resistant to the Streptomycin. The similar result was recorded by Mohd et al. [18]. In contrast with present study high resistance was reported 57.89 per cent by Thaker et al. [22]. Ebrahim et al. [23] found that all E. coli O157 isolates were susceptible to Streptomycin.

All the $E$. coli isolates were found to be sensitive to Co-trimoxazole in the present study. But least reistance were recorded by Sabry and Elmalt [24], Onono et al. [25], Thaker et al. [22]. Mohd et al. [18] reported 60 per cent sensitivity to co-trimoxazole.

In the present study, 6.52 per cent of $E$. coli isolates from raw milk and various milk products were resistant to Cefotaxime, in contrast with present finding higher resistance was recorded by Mahami et 
al. [26] and Mohd et al. [18].

Studies showed that the antibiotic resistance bacteria which exist in the milk of infected animals can be transmitted to human by the ingestion of raw milk or milk products such as cheese, ice cream, mawa, and dahi.

Detection of virulence genes: In this study, out of 80 E. coli isolates, 25 isolates $(31.25 \%)$ were positive for stx genes, similar results for lower per cent of stx gene positive isolates were reported by Kalliopi et al. [27], Mansouri-Najand and Khalili [28], Caro et al. [29], Stephan et al. [30], Islam et al. [31], Ebrahim et al. [23], Farzan et al. [16], Mohd et al. [18]. On the other hand, high per cent of stx positive isolates were reported by Martin and Beutin [32] and Njage et al. [33].

In the present study $12(15.00 \%)$ E. coli isolates found positive for stxlgene and $18(22.50 \%) E$. coli isolates found positive for $s t x 2$ gene. Similar finding of predominance of stx 2 producing strains were reported by Sabry and Elmalt [24], Rey et al. [34], Bandyopadhyay et al. [15]. In contrast with present study predominance of $s t x 1$ producing strains were reported by Lih Ching et al. [35], Caro et al. [29], Martin and Beutin [32], Njage et al. [33], Farzan et al. [16], Kalliopi et al. [27], Mohd et al. [18].

Out of $80 \mathrm{E}$. coli isolates from raw milk and various milk products, 7 isolates $(8.75 \%)$ were positive for eaeA gene. Similar findings were reported by Lih Ching et al. [35], Lorusso et al. [36], Adjehi et al. [37], Bandyopadhyay et al. [15], Mohd et al. [18]. In contrast to present study high prevalence has also been recorded by Karns et al. [38] and Njage et al. [33]. In some study, not any isolates were found positive for eae $A[23,29,30]$.

In this study, none of the isolate was positive for $r f b \mathrm{O} 157$ gene. The similar results were reported by Lih Ching et al. [35], Caro et al. [29], and Stephan et al. [30]. In contrast to present study, Mansouri-Najand and Khalili [28] reported one E. coli $\mathrm{O} 157$ from cheese samples.

\section{Conclusion}

The majority of raw milk and various milk products samples were found to be contaminated or carried $E$. coli infections, which require strict management for effective measures for hygiene and sanitary practice. The high percentage resistance in bacterial isolates to ampicilin, oxytetracycline, streptomycin and nalidixic acid requires further research. Continuous efforts are required to reduce the resistance burden in human by strict monitoring of antibiotic resistance of $E$. coli from milk and various milk products samples. PCR based molecular epidemiological studies are required for detection of all types of pathogenic as well as zoonotic potential strains of $E$. coli isolates for future research.

\section{Authors' contributions}

PKV, JBN and MNB conceived and designed the study. PKV perfomed the whole study. PKV drafted and revised the manuscript with the help of JBN and MNB. All authors read and approved the final manuscript.

\section{Acknowledgements}

The authors are thankful to The Department of Veterinary Public Health, Anand Agricultural University, Anand for financial support and necessary facilities for this research.

\section{Competing interests}

The authors declare that they have no competing interests.

\section{References}

1. FAO (Food and Agriculture Organization), (2011) Food Outlook, Global Market Analysis $17^{\text {th }}$ October 2011, pp. 43-44. http://www.fao.org/giews/english/fo/index.htm. Retrieved on 10/04/2013.

2. Oliver, S. P., Jayarao, B. M. and Almeida, R. A. (2005) Foodborne pathogens in milk and the dairy farm environment: food safety and public health implications. Food borne Pathogenic Dis. 2(2): 115-129.

3. Torkar, K. G. and Teger S. G. (2008) The Microbiological quality of raw milk after introducting the two day's milk collecting system. Acta Agri. Slovenica. 92(1): 61-74.

4. Srinu, B., Vijaya Kumar, A., Shashi Kumar, M., Narayana, B. V. L. and Madhava Rao T. (2012) Assessment of microbiological quality and associated health risks of raw milk sold in and around Hyderabad city. Int. J. Pharm. Bio. Sci. 3(4): 609-614.

5. Kaufmann M, Zweifel C, Blanco M, Blanco JE, Blanco J, Beutin L, Stephan R (2006) Escherichia coli O157 and nonO157 Shiga toxin-producing Escherichia coli in fecal samples of finished pigs at slaughter in Switzerland. J. Food Prot. 69:260-266.

6. Brett KN, Hornitzky MA, Bettelheim KA, Walker MJ, Djordjevic SP (2003) Bovine non-O157 Shiga toxin 2containing Escherichia coli isolates commonly possess stx2ed1933 and/or stx2vhb subtypes. J. Clin. Microbiol. 41:27162722.

7. Schrade, J. P. and Yager, J. (2001) Implication of milk and milk products in food disease in France and in different industrialized countries. Int. J. Food Microbiol. 67: 1-17.

8. Kumar, R., Surendran, P. K. and Thampuran, N. (2008) Evaluation of culture, ELISA and PCR assays for the detection of Salmonella in seafood. Letters in Applied Microbiol. 46(2): 221-226.

9. Edwards, P. R. and Ewing, W. H. (1972) Identification of Enterobacteriaceae. Emerg. Infect. Dis. 12: 154-159.

10. Bauer, A. W., Kirby, W. M. M., Sherris, J. C. and Turck, M. (1966) Antibiotic susceptibility testing by standard single disk method. Am. J. Clin. Pathol. 45: 493-496.

11. Paneto, B. R., Schocken-Iturrino, R. P., Macedo, C., Santo, E. and Marin, J. M. (2007) Occurrence of toxigenic Escherichia coli in raw milk cheese in Brazil. Arq. Bras. Med. Vet. Zootec. 59: 508-512.

12. El-Jakee, J. K., Mahmoud, R. M., Samy, A. A., El-Shabrawy, M. A., Effat, M. M. and El-Said, W. A. (2012) Molecular Characterization of $E$. coli Isolated from Chicken, Cattle and Buffaloes. Int. J. Microbiol. Res. 3(1): 64-74.

13. Dhanashree, B. and Mallya, P. S. (2008) Detection of shigatoxigenic Escherichia coli (STEC) in diarrhoeagenic stool \& meat samples in Mangalore, India. Indian J. Med. Res. 128: 271-277.

14. Soomro, A. H., Arain, M. A., Khaskheli, M. and Bhutto, B. (2002) Isolation of Escherichia coli from raw milk and milk products in relation to public health sold under market condition at Tandojam. Pak. J. Nutr. 13: 151-152.

15. Bandyopadhyay, S., Lodh, C., Rahaman, H., Bhattacharya, D., Bera, A. K., Ahmed, F. A., Mahanti, A., Samanta, I., Mondal, D. K., Sarkar, S., Dutta, T. K., Maity, S., Paul, V., Ghosh, M. K., Sarkar, M. and Baruah, K. K. (2011) Characterization of shiga toxin producing (STEC) and enteropathogenic Escherichia coli (EPEC) in raw yak (Poephagus grunniens) milk and milk products. http://dx. 
doi.org/10.1016/j.rvsc.2011.12.011.10/04/2013.

16. Farzan, R., Rahimi, E. and Momtaz, H. (2012) Virulence properties of Shiga Toxin-Producing Escherichia coli isolated from Iranian raw milk and dairy products. Slov. Vet. Res. 49(4): 159-66.

17. Nanu, E., Latha, C., Sunil, B., Thomas M. and Menon, K. V. (2007) Quality assurance and public health safety of raw milk at the production point. Am. J. Food Technol. 2: 145-152.

18. Mohd, R., Kotwal, S., Malik, M. A. and Prevalence, M. (2013) Genetic profile of virulence determinants and multidrug resistance of Escherichia coli isolates from foods of animal origin. Vet World, 6; 139-142, doi:10.5455/ vetworld.2013.139-142.

19. Fadel, H. M. and Ismail, J. (2009) Prevalence and Significance of Staphylococcus aureus and Enterobacteriaceae species in Selected Dairy Products and Handlers. Int. J. Dairy science. 4(3): 100-108.

20. Singh, P. and Prakash, A. (2008) Isolation of Escherichia coli, Staphylococcus aureus and Listeria monocytogenes from milk products sold under market conditions at agra region. Acta. Agriculturae Slovenica. 92(1): 83-88.

21. Amany, M., Shalaby. and Marcel F. G. (2008) Occurrence of Escherichia coli O157:H7 in some dairy products at PortSaid City. Assiut Vet. Med. J. 54(119): 175-186.

22. Thaker, H. C., Brahmbhatt, M. N. and Nayak, J. B. (2012) Study on occurrence and antibiogram pattern of Escherichia coli from raw milk samples in Anand, Gujarat, India. Vet. World. 5(9): 556-559.

23. Ebrahim R., Sepehr S. C. and Pouya P. (2011) Prevalence and antimicrobial resistance of Escherichia coli O157 isolated from traditional cheese, ice cream and yoghurt in Iran. African J. Microbiol. Res. 5(22): 3706-3710.

24. Sabry A. H. and Elmalt, L. M. (2008) Informally raw milk and kareish cheese investigation on the occurrence of toxigenic Escherichia coli in qena city, egypt with emphasis on molecular characterization. Ass. Univ. Bull. Environ. Res. 11(2): $35-42$.

25. Onono, J. O., Kangethe, E. K. and Ogara, W. O. (2010) Antimicrobial susceptibility of non-sorbitol fermenting Escherichia coli isolated from cattle feaces and milk samples African J. Microbiol. Res. 4(16): 1703-1707.

26. Mahami, T., Odonkor, S., Yaro, M. and Adu-Gyamfi, A. (2011) Prevalence of antibiotic resistant bacteria in milk sold in Accra. Int. Res. J. Microbiol. 2(4): 126-132.

27. Kalliopi, R., Valentina, A. and Luca, C. (2012) Prevalence of Shiga toxin producing Escherichia coli in food products of animal origin as determined by molecular methods. Int. J. Food Microbiol. 154(1-2): 37-43.

28. Mansouri-Najand, L. and Khalili, M. (2007) Detection of shiga-like toxigenic Escherichia coli from raw milk cheeses produced in Kerman-Iran. Veterinarski Arhiv. 77(6): 515-522.

29. Caro, I., Maria, R. and Garcia-Armesto. (2007) Occurrence of Shiga toxin producing Escherichia coli in a Spanish raw ewe's milk cheese. Int. J. Food Microbiol. 116(3): 410-413.

30. Stephan, R., Schumacher, S., Corti, S., Krause, G., Danuser, J. and Beutin, L. (2008) Prevalence and characteristics of Shiga toxin-producing Escherichia coli in Swiss raw milk cheeses collected at producer level. J. Dairy Sci. 91(7): 2561-2565.

31. Islam, M. A., Mondol, A. S., Azmi, I. J., De Boer, E., Beumer, R. R., Zwietering, M. H., Heuvelink, A. E. and Talukder, K. A. (2010) Occurrence and characterization of Shiga toxinproducing Escherichia coli in raw meat, raw milk and street vended juices in Bangladesh. Foodborne Pathogens and Disease. 7(11): 1381-1385.

32. Martin, A. and Beutin, L. (2011) Characteristics of Shiga toxin-producing Escherichia coli from meat and milk products of different origins and association with food producing animals as main contamination sources. Int. $J$. Food Microbiol. 146: 99-104.

33. Njage, P. M. K., Jans, C. Wangoh, J., Lacroix C. and Meile, L. (2012) Detection, isolation and molecular characterisation of Shigatoxigenic O157 and non-O157 Escherichia coli in raw and fermented camel milk. African J. Microbiol. Res. 6(31): 6031-6038.

34. Rey, J., Sanchez S., Blanco J. E., Hermoso de Mendoza, J., Hermoso de Mendoza, M., Garcia., Tejero, N., Rubio, R. and Alonso, J. M. (2006) Prevalence, serotypes and virulence genes of Shiga toxin-producing Escherichia coli isolated from ovine and caprine milk and other dairy products in Spain International. J. Food Microbiol. 107(2): 212-217.

35. Lih Ching, C., Fang-Ming, L. and Daniel, Y. S. (2002) Prevalence of Shiga Toxin-producing Escherichia coli in feces and raw milk of domestic cattle and sheep. J. Food and Drug Analysis. 10(1):39-46.

36. Lorusso, V., Dambrosio, A., Quaglia, N. C., Parisi, A., La Salandra, G., Lucifora, G., Mula, G., Virgilio, S., Carosielli, L., Rella, A., Dario, M. and Normanno, G. (2009) Verocytotoxin-producing Escherichia coli O26 in raw water buffalo (Bubalus bubalis) milk products in Italy. J. Food Prot. 72(8): 1705-1708.

37. Adjehi, D., Guei, T., Louise, O. A., Etienne, D., Marcellin, D. and Mireille, D. (2010) Gastroenteritis E. coli Carried by Milk Products Sold in the Street of Abidjan, Cote d'Ivoire. European J. Sci. Res. 39(1): 143-152.

38. Karns, J. S., Van Kessel, J. S., McClusky, B. J. and Perdue, M. L. (2007) Incidence of Escherichia coli 0157:H7 and E. coli virulence factors in US bulk tank milk as determined by polymerase chain reaction. J. Dairy Science. 90(7): 32123219 . 